\title{
Efficient Plant Regeneration from Petiole Protoplasts of Sweet Potato cv. 'Genki'
}

\author{
Jing-shan WANG*, Satoru TAURA*, Muneharu SATO* and Teiji KOKUBU*
}

Received 21 August 1997; accepted 25 September 1997

Somatic hybridization of sweet potato (Ipomoea batatas Lam.) by cell fusion is one of the possible means for overcoming natural barriers of various kinds of cross incompatibility [1] and the efficiency of production of somatic hybrids depends on the frequency of plant regeneration from protoplasts [2]. There are several reports on plant regeneration from protoplasts of sweet potato [1, 3-9]. However, most of these studies failed to reach the practical level in terms of regeneration frequency. The lack of an efficient plant regeneration system from protoplasts has been a major problem for the application of somatic hybridization in sweet potato. Therefore, in this paper we described an efficient plant regeneration method using petiole protoplasts of sweet potato $\mathrm{cv}$. 'Genki'.

In the first step for increasing the frequency of plant regeneration from protoplasts of sweet potato, adequate culture conditions for inducing plant regeneration from petiole tissues of cv. 'Genki' were studied. The petiole explants were cultured on the MS medium supplemented with $2,4-\mathrm{D}(0.02,0.05 \mathrm{mg} / l), 0.5 \mathrm{mg} / l$ kinetin, $3.0 \%$ sucrose and $0.8 \%$ agar at $\mathrm{pH} 5.8$, under 13 hours day-light (3,000 lux) condition at $27^{\circ} \mathrm{C}$. After three to four weeks of culture, the formed calli were transferred onto either MS basal medium or the medium supplemented with $3.0 \mathrm{mg} / l$ BAP, $3.0 \%$ sucrose and $0.8 \%$ agar at $\mathrm{pH} 5.8$ followed by transferring onto MS basal medium, for plant regeneration. They were subcultured for two to three weeks on the basal medium under 13 hours day-light (3,000 lux) condition at $27^{\circ} \mathrm{C}$. The result showed that induction medium supplemented with $0.05 \mathrm{mg} / l 2,4-\mathrm{D}$ and 0.5 $\mathrm{mg} / l$ kinetin combined with regeneration medium supplemented with $3.0 \mathrm{mg} / l$ BAP was the most effective for promoting the frequency of shoot regeneration (Table $\mathbf{1}$ ).

As the second step, protoplast culture was carried out based on the protocol mentioned above. Protoplasts were isolated from petioles of sweet potato $\mathrm{cv}$. 'Genki' by the means of Wang et al. [10] and cultured in a modified liquid-MS medium in the dark at $27^{\circ} \mathrm{C}$. The liquid medium was composed of $1 / 2 \mathrm{MS}$ inorganic salts (excepted $\mathrm{NH}_{4} \mathrm{NO}_{3}$ ), MS vitamins, 50.0 $\mathrm{mg} / l$ casein hydrolysate, $0.05 \mathrm{mg} / l 2,4-\mathrm{D}, 0.5 \mathrm{mg} / l$ kinetin, $0.6 \mathrm{M}$ mannitol and $1.0 \%$ sucrose at $\mathrm{pH} 5.8$. After three to four weeks of incubation, the mannitol content was reduced from $0.6 \mathrm{M}$ to $0.3 \mathrm{M}$ and the sucrose content was increased from $1.0 \%$ to $2.0 \%$. Then the formed colonies were cultured in liquid MS medium containing $3.0 \%$ sucrose and the same concentrations of 2,4-D and kinetin without either mannitol and casein hydrolysate.

The first cell division occurred within four days of culture (Fig. 1-A and B). Then some of the cells divided and developed into cell clusters and small calli (Fig. 1-C and D). Subsequently, for callus proliferation, the small calli were transferred onto the solid MS medium containing $2,4-\mathrm{D} \quad(0.05 \sim 0.2 \mathrm{mg} / l)$, kinetin $(0$ or $0.5 \mathrm{mg} / \mathrm{l}), 3.0 \%$ sucrose and $0.8 \%$ agar

Table 1. Plant regeneration from petioles of sweet potato cv. 'Genki'.

\begin{tabular}{cccc}
\hline $\begin{array}{c}\text { Callus induction medium } \\
2,4-\mathrm{D}(\mathrm{mg} / l)\end{array}$ & $\begin{array}{c}\text { Regeneration medium } \\
\mathrm{BAP}(\mathrm{mg} / l)^{* 1}\end{array}$ & \% Calli regenerating shoots \\
\hline 0.02 & 0.5 & 0 & 26.1 \\
0.02 & 0.5 & 1.0 & 22.7 \\
0.02 & 0.5 & 3.0 & 25.0 \\
0.05 & 0.5 & 0 & 67.7 \\
0.05 & 0.5 & 1.0 & 37.5 \\
0.05 & 0.5 & 3.0 & 81.8 \\
\hline
\end{tabular}

${ }^{* 1} \mathrm{MS}$ medium $+3.0 \%$ sucrose $+0.8 \%$ agar, $\mathrm{pH} 5.8$.

${ }^{* 2} \mathrm{MS}$ medium $+3.0 \%$ sucrose $+0.8 \%$ agar, $\mathrm{pH} 5.8$. The calli that were cultured on the medium supplemented with BAP regenerated shoots after transferring them onto hormone-free medium. 


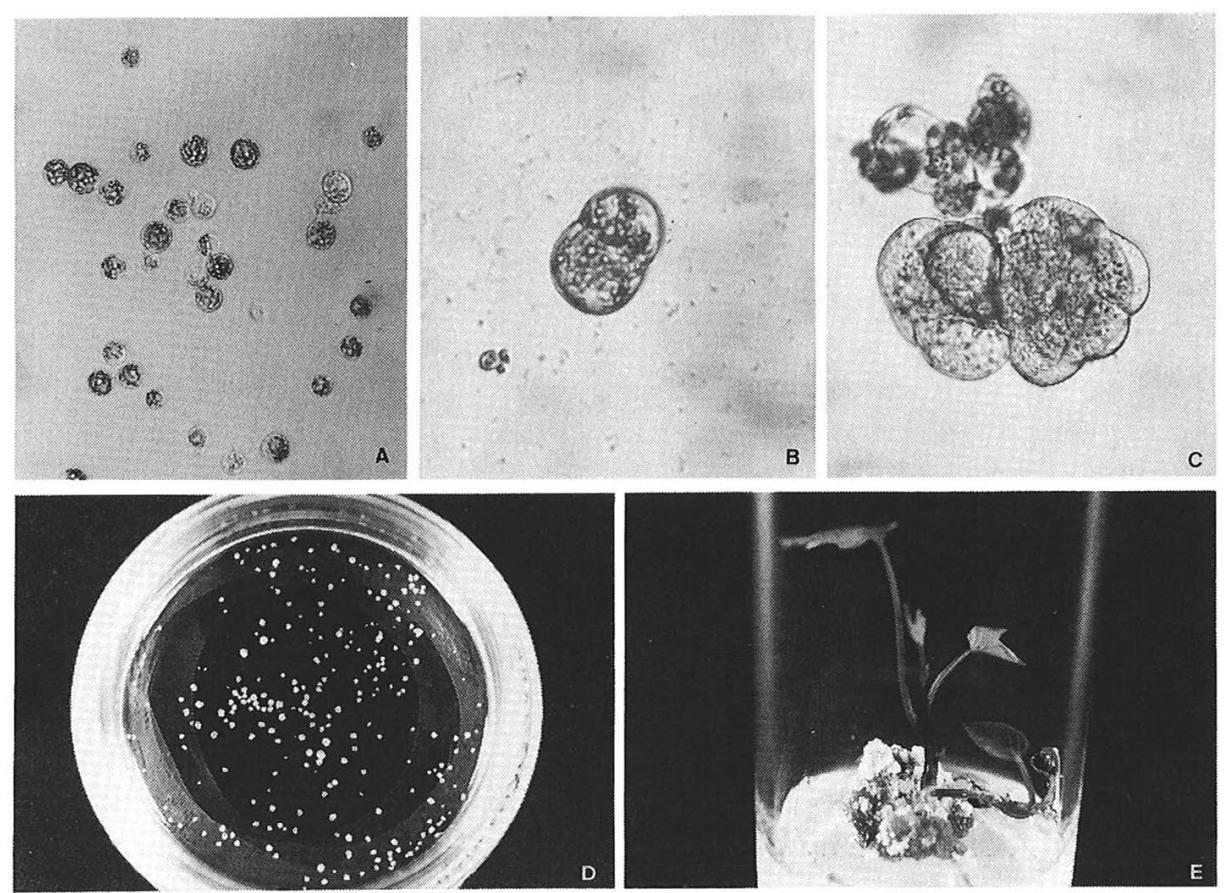

Fig. 1 Plant regeneration from protoplasts of sweet potato cv. 'Genki'.

A: Freshly isolated petiole protoplasts.

B: First cell division, after 4 days of culture.

C: A protoplast-derived cell cluster, after 2 weeks of culture $(0.1 \sim 0.2 \mathrm{~mm}$ in diameter).

D: Micro-calli derived from protoplasts, after $8 \sim 9$ weeks of culture $(1.0$

$\sim 2.0 \mathrm{~mm}$ in diameter).

E: A shoot regenerated from protoplast-derived callus.

at pH 5.8. They were further transferred onto either MS basal medium or regeneration MS medium sup plemented with $3.0 \mathrm{mg} / l$ BAP, $3.0 \%$ sucrose and $0.8 \%$ agar at $\mathrm{pH} 5.8$ followed by transferring onto MS basal medium. The calli were subcultured for two to three weeks on the basal medium under 13 hours day-light $(3,000$ lux $)$ condition at $27^{\circ} \mathrm{C}$.

The results of shoot regeneration from protoplast- derived calli of 'Genki' are shown in Table 2 (Fig. 1E). It was obvious that the regeneration frequencies were significantly influenced by the concentration of 2 , 4-D and kinetin added to callus proliferation medium as well as BAP added to regeneration medium. The highest rate $(60.0 \%)$ was obtained from the calli that had been cultured on the proliferation medium supplemented with $0.05 \mathrm{mg} / / 2,4-\mathrm{D}$ and $0.5 \mathrm{mg} / l$ kinetin

Table 2. Plant regeneration from protoplasts of sweet potato cv. 'Genki'.

\begin{tabular}{|c|c|c|c|c|c|}
\hline $\begin{array}{c}\text { Prolifera } \\
2,4-D \\
(\mathrm{mg} / \mathrm{l})\end{array}$ & $\begin{array}{l}\text { n medium } \\
\text { kinetin } \\
(\mathrm{mg} / l)\end{array}$ & $\begin{array}{l}\text { Regeneration } \\
\text { medium* } \\
\operatorname{BAP}(\mathrm{mg} / l)\end{array}$ & $\begin{array}{c}\text { No. of calli } \\
\text { transferred } \\
\text { A }\end{array}$ & $\begin{array}{l}\text { No. of calli } \\
\text { regenerating shoots } \\
B(B / A \times 100)\end{array}$ & $\begin{array}{l}\text { No. of shoots regenerated, } \\
\text { No. of calli regenerating } \\
\text { shoots }\end{array}$ \\
\hline 0.05 & 0 & 0 & 29 & $1(3.4)$ & 1 \\
\hline 0.1 & 0 & 0 & 20 & 0 & 0 \\
\hline 0.05 & 0.5 & 0 & 18 & $1(5.6)$ & 1 \\
\hline 0.1 & 0.5 & 0 & 22 & $1(4.5)$ & 1 \\
\hline 0.2 & 0.5 & 0 & 20 & 0 & 0 \\
\hline 0.05 & 0 & 3.0 & 26 & $1(3.8)$ & 1 \\
\hline 0.1 & 0 & 3.0 & 20 & 0 & 0 \\
\hline 0.2 & 0 & 3.0 & 25 & 0 & 0 \\
\hline 0.05 & 0.5 & 3.0 & 20 & $12(60.0)$ & 1.7 \\
\hline 0.1 & 0.5 & 3.0 & 20 & $7(35.0)$ & 1.6 \\
\hline 0.2 & 0.5 & 3.0 & 24 & $5(20.8)$ & 1.2 \\
\hline
\end{tabular}

*The calli that were cultured on regeneration medium supplemented with BAP regenerated shoots after transferring them onto hormone-free medium. 
and the regeneration medium supplemented with 3.0 $\mathrm{mg} / l$ BAP. The percentages of calli regenerating shoots were clearly reduced with an increase in 2,4-D concentration. Similarly, when the proliferation media without kinetin or the regeneration medium without BAP were used, the calli gave a very low percentage of shoot regeneration $(0 \sim 5.6 \%)$. This result showed the importance of cytokinin on plant regeneration from protoplasts [11-15]. However, in the other cultivars of sweet potato, namely 'Bitambi' and 'White Star', our study showed that regeneration medium supplemented with BAP inhibited plant regeneration (data not shown). This suggests that the effect of BAP on plant regeneration is different with genotypes.

In the present study, adventitious shoots were easily induced and our method proved its superiority to protocols reported previously [1, 3-9]. It is considered to be important for obtaining efficient plant regeneration to use the lower concentration of 2,4-D combined with kinetin into the medium. This also appeared to be true in 'Bitambi' and 'White Star' (data not shown). However, BAP inhibited the promotion of adventitious shoots from these varieties indicating the role of BAP was different in various cultivars.

The plant regeneration system established here should be useful for the production of somatic hybrids through cell fusion and gene transfer.

\section{Acknowledgment}

We are grateful to Dr. T. C. Katayama, Professor of Laboratory of Crop Science, Faculty of Agriculture, Kagoshima University, for useful suggestions and critical reading of the manuscript.

\section{References}

[1] Murata, T., Fukuoka, H., Kishimoto, M., 1994. Breeding Science, 44: 35-40.

[2] Yamaguchi, J., Shiga, T., 1993. Japan. J. Breed., 43: 173-182.

[3] Murata, T. Hoshino, K., Miyaji, Y., 1987. Japan. J. Breed., 37: 291-298.

[4] Murata, T., Hoshino, K., Fukuoka, H., Miyaji, Y., 1989. Proc. Fac. Agr. Kyushu Tokai Univ., 8 : 23-27.

[5] Sihachakr, D., Ducreux, G., 1987. Plant Cell Reports, 6: 326-328.

[6] Perera, S. C., Ozias-Akins, P., 1991. J. Amer. Soc. Hort. Sci., 116: 917-922.

[ 7 ] Liu, Q. C., Kokubu, T., Sato, M., 1992. Mem. Fac. Agr. Kagoshima Univ., 28: 47-53.

[8] Liu, Q.C., Wang, J.S., Kokubu, T., Sato, M., 1995. Acta Agri. Sinica., 21: 25-28.

[ 9 ] Belarmino, M. M., Abe, T., Sasahara, T., 1994. Plant Cell, Tissue, Organ Culture, 37: 145-150.

[10 ] Wang, J.S., Sakai, T., Taura, S., Sato, M., Kokubu, T., 1997. Breeding Science, 47: 135-139.

[11] Liu, Q. C., Kokubu, T., Sato, M., 1990. Japan. J. Breed., 40: 321-327.

[12 ] Liu, Q. C., Kokubu, T., Sato, M., 1991. Japan. J. Breed., 41: 103-108.

[13 ] Flick, C. E., Evans, D. A., Sharp, W. R., 1983. In "Handbook of Plant Cell Culture" Volume 1 (eds. by Evans, D. A., Sharp, W. R., Ammirato, P. V., Yamada, Y.), p. 13-81, Macmillan, New York.

[ 14 ] Otani, M., Shimada, T., 1988. Japan. J. Breed., 38: 205-211.

[15] Belarmino, M. M., Abe, T., Sasahara, T., 1992. Japan. J. Breed., 42: 109-114. 